\title{
Performance of millennial lecturers during pandemic Covid-19
}

\author{
Yohana F. Cahya Palupi Meilani ${ }^{*}$ \\ Management Department, Universitas Pelita Harapan, Indonesia
}

\begin{tabular}{l} 
Article Info \\
\hline Article history: \\
Received Apr $14^{\text {th }}, 2021$ \\
Revised Jul $12^{\text {th }}, 2021$ \\
Accepted Aug $22^{\text {th }}, 2021$ \\
\hline
\end{tabular}

\section{Keyword:}

Work motivation

Work climate

Job satisfaction

Performance

Millennal

\begin{abstract}
This study aims to identify the effect of work motivation and work climate, job satisfaction on the performance of millennial lecturers of private Universities LLDIKTI III during pandemic Covid-19. The sudden change in the situation during the Covid-19 pandemic has an impact and unpreparedness in mastering the technology that must be carried out will bring its own stressful situation for lecturers and have an impact on lecturer performance. This study uses quantitative research methods by distributing questionnaires and using purposive sampling technique where the respondent is millenial lecturer and who has worked for at least 2 years, who already have academic level (JJA) minimum Asisten Ahli, lecturer' certification (serdos), and have worked as permanent lecturers. The research sample collected in this study amounted to 200 respondents with $100 \%$ response rate. The statistical analysis method used in this study uses SPSS software. The results of this study are that work motivation has a positive effect on the performance of millennial lecturers, work climate has a positive effect on the performance of millennial lecturers and job satisfaction has a positive effect on the performance of millennial lecturers. The contribution of this research can be used in the field of education, especially for private universities management in improving their milllennial lecturers performance.
\end{abstract}

(C) 2021 The Authors. Published by IICET.

This is an open access article under the CC BY-NC-SA license

(https://creativecommons.org/licenses/by-nc-sa/4.0)

\section{Corresponding Author: \\ Yohana F. Cahya Palupi Meilani, Universitas Pelita Harapan \\ Email: yohana.meilani@uph.edu}

\section{Introduction}

High-quality education requires the role of education personnel, including lecturers. In Law no. 20 of 2003 concerning the National Education System Article 1 paragraphs 5 and 6, the definition of education personnel is a member of the community who provides abilities and knowledge and is appointed to carry out educational activities. Meanwhile, education is defined as education personnel who have special academic licenses such as teachers, lecturers and so on and participate in organizing educational programs. All lecturers carry out the performance process through teaching, research, community service (Tridharma). Other wise, situation began with the Covid-19 pandemic that hit all countries including Indonesia. The covid 19 disaster has had a huge impact on the world of education, including universities in doing Tridharma. Whereas, the main actors in the world of universities who transform knowledge are lecturers. The task of Human Resource Management in Higher Education is to manage all lecturers across generations to be able to show their best performance, especially the millennial lecturers whose numbers continue to increase.

The millennial generation is adopted by America and Europe which defines it as a group that is aware of technology (Zhao, 2018; Ansar et al., 2019). That is why, if the Indonesian people who were born in the 
millennial generation era but cannot empower technology, then they cannot be called the millennial generation (Luntungan et al., 2014). Reinforcing this statement, Kottler and Armstrong (2014) state that the millennial generation is a generation that is very close to using technology. Millennials in general can work with computers, iphones, ipads, and other social media to make it easier for them to work. The task of millennial lecturers is not only to carry out the teaching process through mere mastery of technology but also to develop themselves. Referring to Tridharma, lecturers have the opportunity to improve themselves through further studies, attend seminars, training, conduct research, and share knowledge through community service activities. The self-development in question is an act of increasing the knowledge and skills of lecturers, so that they have a positive impact on teaching and foster professionalism in the work that millennial lecturers must have.

The guidance and supervision of higher education institutions, both Public Universities (PTN) and Private Universities (PTS) in certain areas based on the Higher Education Law No. 12 of 2012 which is called the Higher Education Service Institute (LLDIKTI). LLDIKTI has the function of providing facilities for improving the quality of higher education externally, evaluating, and reporting on improving the quality of both PTN and PTS in its area. Compared to all LLDIKTI in Indonesia, LLDIKTI III serves the most universities. LLDIKTI III service coverage area is around DKI Jakarta and its surroundings. LLDIKTI III serves 5 PTN and 316 PTS. There are 133 private universities served by LLDIKTI III which have been accredited. In LLDIKTI III, there are 12 A-accredited universities, 65 B-accredited universities, and $56 \mathrm{C}$ accredited universities. The number of A-accredited private universities in LLDIKTI III is the highest compared to other LLDIKTI (kelembagaan. ristekdikti.go.id, 2019).

As a justification for the reason why this research topic needs to be raised, a preelimanary or exploratory study was conducted by distributing questionnaires to 30 millennial lecturer respondents who already have JJA, serdos, and have worked as permanent lecturers for at least two years at PTS who have a minimum accreditation B in LLDIKTI III. The distribution of the questionnaires was carried out in a convenience way by selecting respondents who were easy and willing to be accessed in data collection. Exploration is done with open-ended questions. The questions presented in the questionnaire, such as the most important factors in HR that need to be considered by PTS in managing millennial lecturers. The results of these questions show that $58 \%$ of respondents say that performance is an important thing in the management of millennial lecturers. The sudden change in the situation during the Covid-19 pandemic has an impact and unpreparedness in mastering the technology that must be carried out will bring its own stressful situation for lecturers and have an impact on lecturer performance. Furthermore, as many as 35\% stated the need for turnover, and $10 \%$ of respondents stated the need to manage organizational culture. Furthermore, the same respondents were asked questions about what factors can affect the life satisfaction of millennial lecturers. There are three factors that occupy the top positions, namely $35 \%$ answered work motivation, $30 \%$ answered work climate, and $26 \%$ answered job satisfaction. Therefore, the top three factors were chosen as variables to explain the performance of millennial lecturers in this study.

According to Juniari (2015), motivation is when a person feels awake and more focused in activities related to the workplace. According to Samsudin (2010), motivation is a condition by directing employees to be more focused on achieving company goals. Motivation can also be said as a person's encouragement to do something, the drive can be internal or external to achieve goals from the company (Mulyadi, 2015). There are principles in motivating work, including: (1). Participation. Employee involvement in important processes such as determining targets to be achieved together is one of the things that can motivate work because they feel an important part of the company. (2). Good communication between fellow employees as well as between superiors and employees is one of the factors that play an important role, in the communication process superiors can inform things related to achieving targets and provide information needed by employees.(3). Recognizing Subordinates' Contributions In the process of achieving company goals and targets, superiors should also acknowledge that in the process there is also the work of employees, this can motivate the work of employees.(4). Delegation of Authority In the work process, sometimes superiors have to provide opportunities for employees to make certain decisions related to their fields, this can make employees motivated to do better in work (Mulyadi, 2015).

Then Surachim (2008) stated that organizational climate is a way of employees' views about the internal environment of the organization that are perceived by them then also affect the members in it. Meanwhile, Wirawan (2013) complements that organizational climate is an internal environment that lasts a long time and is experienced by members of the organization and can affect the way they behave. There are five factors that influence the climate of an organization, namely: (1) External Environment Similar businesses usually have the same general climate as well. (2) Organizational Arrangements. What is regulated in the organization will be the most influential factor in the organizational climate. (3) The strategy will indirectly affect the climate, in 
In carrying out their duties, members will definitely be given a strategy and this will certainly have a direct effect on the work climate. (4) Strength of History means that the longer the organization has been formed, the stronger its historical strength is, this is one that affects the organizational climate. (5) Leadership. Different leadership styles will also affect different climates, so getting a leader who can create a good climate will also be very good (Susanty, 2012).

While, job satisfaction is a feeling of pleasure or not from employees to their work (Masnita et al., 2019). According to Wibowo (2014), defining job satisfaction is an attitude towards a person's job, which they see is an award that is received and expected or should be. According to Meilani, Bernarto, Berlianto (2020), there are a number of job satisfaction indicators, namely: 1) The Work Itself. If the job is indeed liked, it will be an indicator of job satisfaction; 2) Salary. Salary and wages are also important, because sufficient wages and salaries are a reason to feel satisfied; 3) Promotion. The opportunity to get a promotion is one that affects job satisfaction; 4) Colleagues. Good and supportive coworkers are one of the simplest indicators of job satisfaction individually; 5) Working Conditions. Good working conditions are certainly desired by everyone, this means that if there are no problems in working conditions, there are also no problems in job satisfaction.

According to Suarningsih and Alamsyah (2013) the meaning of the work performance is from job performance or actual performance. Performance is what is the result of the achievement of employees who have carried out their duties to the standards that have been given. Performance is the result of a whole series as long as a person works with the targets and results that have been set initially (Nuraeni, 2011). Performance is a result that is measured over a certain period of time in a predetermined agreement also before starting it (Diyanti, 2017). Generally, performance can be interpreted as a process in someone's work which then becomes the result to determine whether that person is working right or not (Zeffane and Melhem, 2017).

Millennial lecturer must have an academic license and competence as a teacher, be physically and mentally healthy, and be able to achieve national education goals. If so, then the performance of millennial lecturers will be seen from the competencies they have. The performance of educators is referred to as the result of the achievement of an educator in an institution for education in accordance with what are their duties and responsibilities in achieving educational goals (Asf \& Mustofa, 2013). The performance of an educator can be influenced by several things, including work motivation, work climate and job satisfaction. This is reinforced by research conducted by Diyanti (2017), where work motivation and work climate have a significant effect on the performance of educators. Educators who have high work motivation will increase their performance even higher, besides that the performance of a good educator arises from a conducive work climate. So far, performance research on the millennial generation has been mostly applied to business and health organizations, while research on higher education including private universities has not been widely carried out (Sari, 2018).

\section{Relationship between Work Motivation and Job Satisfaction}

Motivation is an impulse or movement from a person to behave and behave in what is desired that arises from internal and external. Motivation can be an encouragement from others or oneself to do a good job and be able to achieve the targets and goals set (Mulyadi, 2015). This is also supported by the results of Diyanti (2017) which shows that work motivation has a significant effect on job satisfaction. This means that the higher the level of work motivation of a person, the higher the job satisfaction of that person regardless of what motivates a person because the form of motivation of each person or individual can vary depending on what triggers the emergence of work motivation. And vice versa, the lower the level of one's work motivation, the lower one's job satisfaction. Based on this, the first hypothesis is:

\section{H1: Work motivation has a positive effect on job satisfaction of millennial lecturers.}

\section{Relationship between Work Climate and Job Satisfaction}

According to Suarningsih and Alamsyah (2013) organizational climate is an internal environment that lasts a long time and is experienced by members of the organization and can affect the way they behave. Work climate is defined as the perception of organizational policies, practices and procedures that are felt and accepted by individuals in the organization, or individual perceptions of their place of work. Individuals in an organization consider the work climate as an attribute, where this attribute is used in the realization of their existence in the organization (Fu and Deshpande, 2014). A good work climate will also improve the performance of educational staff, because the atmosphere of a comfortable and conducive work environment can support better educational service activities. These results are supported by research conducted by Diyanti (2017) and Novitasari (2020), that the work climate has a significant effect on job satisfaction. This shows that the better the climate of a work environment, the more one's job satisfaction will be. Vice versa, a work climate that is not good or not conducive will cause a person's job satisfaction to be low. Based on this, the second hypothesis is: 
H2: Work climate has a positive effect on job satisfaction of millennial lecturers.

\section{Relationship between Job Satisfaction and Performance}

Education Personnel According to Brahmasari (2008), job satisfaction is a feeling of pleasure or not from employees towards their work. According to Wibowo (2014), job satisfaction is an attitude towards work, what they see is the award received and what is expected or should be received. Educational staff who are satisfied with the work they do, or the salary they receive and a pleasant work environment will increase their sense of job satisfaction and will further improve the performance of education personnel. These results are supported by research conducted by Diyanti (2017), that job satisfaction has a significant effect on performance. The study of Bernarto et al. (2020), also stated that job satisfaction has a positive effect on performance. Based on this, the third hypothesis is:

H3: Job satisfaction has a positive effect on the performance of millennial lecturers.

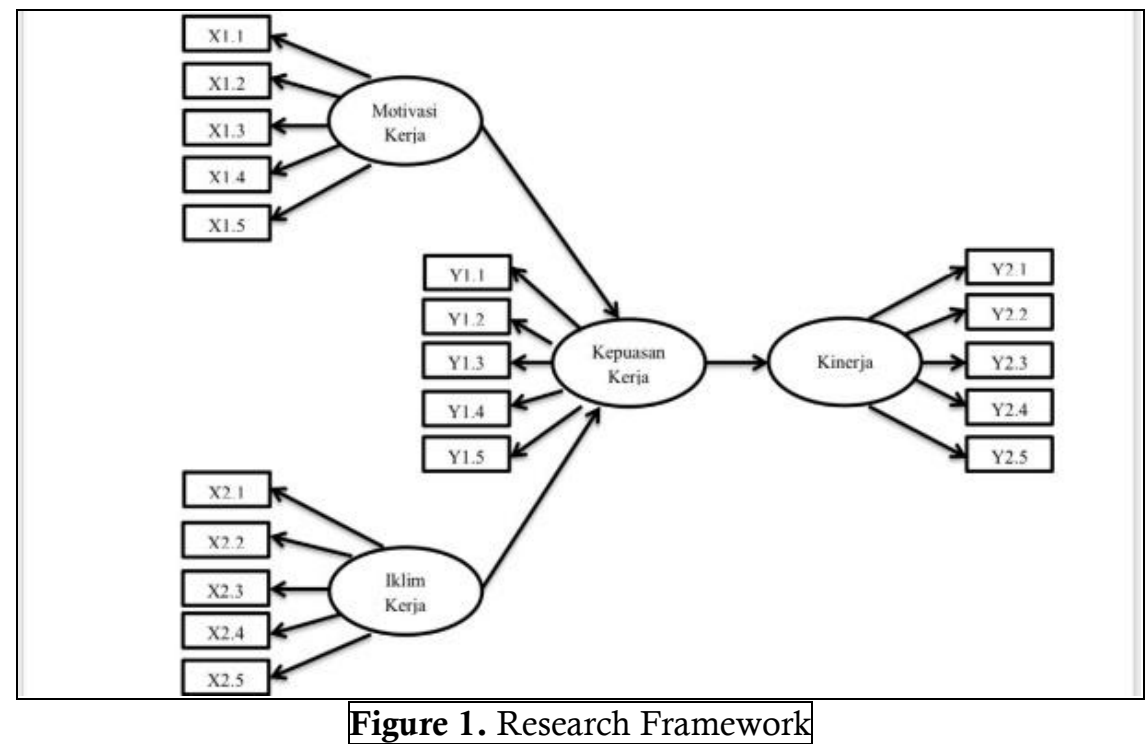

In this study, the research model is built from four variables consisting of motivasi kerja (work motivation), iklim kerja (work climate), kepuasan kerja (job satisfaction) and kinerja (performance) and directional hypotheses because of the indications of a positive relationship of each construct.

\section{Method}

This research uses quantitative research. The design in this study used a descriptive approach. The subjects used in this study as purposive sampling, were 200 millennial lecturer respondents who already have JJA, lecturer's sertification and have worked as permanent lecturers for at least two years at PTS who have a minimum accreditation B in LLDIKTI III. In this study used an individual unit of analysis where data were obtained from individuals/individuals directly, namely from respondents. The interval measurement scale uses a Likert scale with five points. The scale of this study is an interval, which is a scale where individuals or responses that fall into sub categories have the same characteristics. Data collection techniques used are questionnaires and observation. The sampling technique used was purposive sampling.

The data analysis method used validity test is used to determine the feasibility of the items in a list of questions in defining a variable. Reliability test used to show a measure of stability and consistency of the concept of the size of the instrument or measuring instrument, so that the measured value does not change within a certain value (Sugiyono, 2018). While descriptive statistics to analyze data by describing or describing the data that has been collected as it is without intending to draw conclusions that apply to general or generalization. Analysis t test (partial) aims to measure the effect of one independent variable individual in explaining the variation of the dependent variable. Level of significance that use in this $t$ test is at the level of $5 \%(0.05)$. If the value of significance $<0.05$ then it is stated that the independent variable has an effect to the dependent variable, on the contrary. $\mathrm{F}$ test (simultaneous)The $\mathrm{F}$ test is used to test the significance of the effect of the independent variable to the dependent variable together. The researcher's level of significance use in this 
$\mathrm{F}$ test is at the $5 \%$ level (0.05). If the significance value $<0.05$, it is stated that the independent variable has an effect on the variable dependent, and vice versa (Sugiyono, 2018).

\section{Results and Discussions}

This research uses quantitative research. The design in this study used a descriptive approach. The subjects used in this study as purposive sampling, were 200 millennial lecturer respondents who already have JJA, lecturer's sertification and have worked as permanent lecturers for at least two years at PTS who have a minimum accreditation B in LLDIKTI III. In this study used an individual unit of analysis where data were obtained from individuals/individuals directly, namely from respondents. The interval measurement scale uses a Likert scale with five points. The scale of this study is an interval, which is a scale where individuals or responses that fall into sub categories have the same characteristics. Data collection techniques used are questionnaires and observation. The sampling technique used was purposive sampling.

The data analysis method used validity test is used to determine the feasibility of the items in a list of questions in defining a variable. Reliability test used to show a measure of stability and consistency of the concept of the size of the instrument or measuring instrument, so that the measured value does not change within a certain value (Sugiyono, 2018). While descriptive statistics to analyze data by describing or describing the data that has been collected as it is without intending to draw conclusions that apply to general or generalization. Analysis t test (partial) aims to measure the effect of one independent variable individual in explaining the variation of the dependent variable. Level of significance that use in this test is at the level of $5 \%(0.05)$. If the value of significance $<0.05$ then it is stated that the independent variable has an effect to the dependent variable, on the contrary. F test (simultaneous)The $F$ test is used to test the significance of the effect of the independent variable to the dependent variable together. The researcher's level of significance use in this $\mathrm{F}$ test is at the $5 \%$ level $(0.05)$. If the significance value $<0.05$, it is stated that the independent variable has an effect on the variable dependent, and vice versa (Sugiyono, 2018).

\section{RESULTS AND DISCUSSION}

Result

Table 1. Respondents Profile

\begin{tabular}{lll}
\hline Criteria & & Percentage \\
\hline Gender & Male & 59 \\
& Female & 41 \\
& $36-40$ & 38 \\
Working Period & $31-35$ & 36 \\
& 30 and under 30 & 24 \\
Academic Position & More than 4 years & 35 \\
& $3-4$ & 40 \\
& 2 & 25 \\
Married Status & Lektor Kepala (Associate Professor) & 15 \\
& Lektor (Assistent Professor) & 20 \\
& Asisten Ahli (Assistent Professor) & 40 \\
& Non JJA (Lecturer) & 25 \\
& Married & 72 \\
& Single & 28 \\
\hline
\end{tabular}

The profile of respondents based on table 1 consisting of $59 \%$ are male, it can be explained that the majority of lecturers in Indonesia are male, including in LLDIKTI III. With the majority age being 36-40 years, 38\% are classified as Generation $Y$ in the millennial generation. The majority of the working period is $3-$ 4 years as much as $40 \%$ and having the highest level of position is Asisten Ahli as much as $40 \%$. Then, $72 \%$ stated as married.

Then table 2 below explain validity of each item that shows all items of the questionnaire or questionnaire are declared valid, this is based on the basis of decision making where the value of $r$ count $(0.435-0.703)>r$ table (1.95), then all questionnaire item is declared valid. 
Table 2. Validity Test

\begin{tabular}{cccc}
\hline Item & rtabel & rvalue & Status \\
\hline Work Motivation (Motivasi) & & & Valid \\
\hline M1 & 0,195 & 0,453 & Valid \\
\hline M2 & 0,195 & 0,689 & Valid \\
\hline M3 & 0,195 & 0,650 & Valid \\
\hline M4 & 0,195 & 0,465 & \\
\hline M5 & 0,195 & 0,418 & Valid \\
\hline Work Climate (Iklim Kerja) & & & Valid \\
\hline I1 & 0,195 & 0,582 & Valid \\
\hline I2 & 0,195 & 0,672 & Valid \\
\hline I3 & 0,195 & 0,741 & \\
\hline I5 & 0,195 & 0,658 & Valid \\
\hline Job Satisfaction (Kepuasan Kerja) & 0,195 & 0,644 & Valid \\
\hline KK1 & 0,195 & & Valid \\
\hline KK2 & 0,195 & 0,576 & Valid \\
\hline KK3 & 0,195 & 0,703 & Valid \\
\hline KK4 & 0,195 & 0,666 & Valid \\
\hline KK5 & 0,195 & 0,585 & Valid \\
\hline Kerformance (Kinerja) & & 0,562 & Valid \\
\hline K2 & 0,195 & & Valid \\
\hline K3 & 0,195 & 0,669 & Valid \\
\hline K4 & 0,195 & 0,591 &
\end{tabular}

Then table 2 below explain validity of each item that shows all items of the questionnaire or questionnaire are declared valid, this is based on the basis of decision making where the value of $r$ count $(0.435-0.703)>r$ table (1.95), then all questionnaire item is declared valid.

Based on the results of the reliability test on table 3, it is known that all items in the questionnaire or questionnaire are declared reliable, this is based on the basis of decision making where the value of Cronbach's alpha is greater than the standard value of 0.60 . With cronbach alpha of work motivation (0.692), work climate (0.673), job satisfaction (0.677), performance (0.635).

Table 3. Reliability Test

\begin{tabular}{ccc}
\hline Item Variable & Cronbach'sAlpha & Status \\
& & Reliable \\
\hline Work Motivation & 0,692 & Reliable \\
\hline Work Climate & 0,673 & Reliable \\
\hline Job Satisfaction & 0,677 & Reliable \\
\hline Performance & 0,635 &
\end{tabular}

Normality Test is one part of the data analysis requirements test or classical assumption test, meaning that before carrying out statistical analysis to test The hypothesis in this case is regression analysis. Then the research data must be tested for the normality of the distribution. Data which is good is data that is normally distributed. Decision making basis in the K-S normality test shown as table 4 that Asymp significance. Sig. (2tailed) is 0.200 , which is greater than 0.05 . Then it fits on the basis of decision making in the KolmogorovSmirnov normality test in above, it can be concluded that the data is normally distributed. Thus, the assumption or the normality requirements in the regression model have been met. 
Table 4. Normality Test One-Sample Kolmogorov-Smirnov

UnstandardizedResidual

\begin{tabular}{lrr}
\hline $\mathbf{N}$ & & $\mathbf{1 0 0}$ \\
\hline Normal Parameters $^{\mathbf{a}, \mathbf{b}}$ & Mean &, 0000000 \\
& Std. Deviation & 1,97692386 \\
Most Extreme Differences & Absolute &, 040 \\
& Positive &, 037 \\
Test Statistic & Negative &,- 040 \\
Asymp. Sig. (2-tailed) & &, 040 \\
\hline
\end{tabular}

The multicollinearity test is part of the classical assumption test (normality and heteroscedasticity) in multiple linear regression analysis. Purpose of use multicollinearity test is to test whether the regression model is found to exist correlation (strong relationship) between independent variables or independent variables. A good regression model should not have a correlation between variables free or no multicollinearity symptoms occur, result as shown as table 5. From the overall value of the Tolerance of the variables above, it is known that overall has a value greater than 0.10 . Then referring to the basis for decision making in the multicollinearity test can be concluded that there is no symptom of multicollinearity in the model regression.

Table 5. Tolerance Value Test

\begin{tabular}{ll}
\hline Variable & Tolerance Value \\
\hline Work Motivation & 0.776 \\
\hline Work Climate & 0.682 \\
\hline Job Satisfaction & 0.732 \\
\hline
\end{tabular}

Based on the VIF value on table 6 shown that

a. VIF value of work motivation variable is 1.288

b. VIF value of climate variable is 1.466

c. VIF value of job satisfaction variable is 1.366

From the overall VIF value of the variables above, it is known that the whole has a value less than 10.00. Then referring to the base decision making in the $\backslash$ multicollinearity test can be concluded that there is no symptom of multicollinearity in the regression model.

Table 6. Variance Inflating Factor (VIF) Test

\begin{tabular}{ll}
\hline Variable & Tolerance Value \\
\hline Work Motivation & 1.288 \\
\hline Work Climate & 1.466 \\
\hline Job Satisfaction & 1.366 \\
\hline
\end{tabular}

Heteroscedasticity test is part of the classical assumption test in regression analysis that aims to test whether the regression model occurs inequality of variation from the residual value of one observation to another observation. If the variance from the residual value of one observation to another observation is constant, then it is called homoscedasticity, but if the variance is different then is called heteroscedasticity. A good regression model should not happen a symptom of heteroscedasticity. One way to detect the presence or absence of symptoms heteroscedasticity in the regression model is to do the glejser test. Based on the results table 7 known that: 1) Value of sig. Work motivation variable is 0.91 ; 2) Value of sig. climate variable is 0.997 ; 3) Value of sig. job satisfaction variable is 0.229.

From the overall value of sig. the above variables, are known in their entirety has a value greater than 0.05 . Then referring to the basis of decision making in the heteroscedasticity test, it can be concluded that there is no heteroscedasticity symptom in the regression model. 
Table 7. Heteroscedasticity test

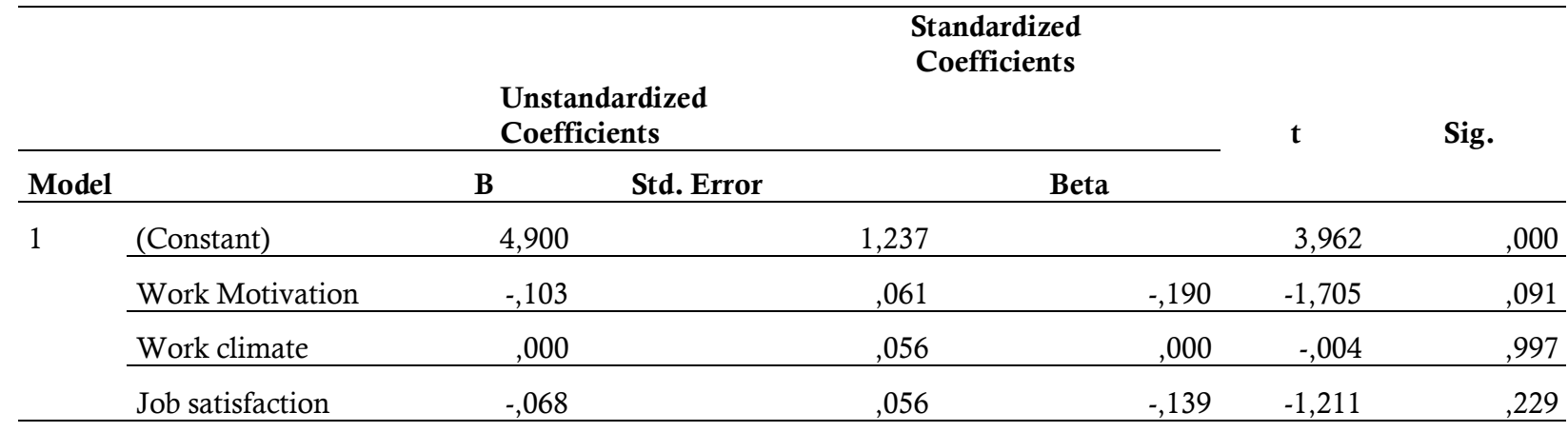

KMO Factor Analysis is an analytical technique that includes information about grouping factor variables in a study. Analysis factor aims to filter out which variable is the most superior or the most dominant of several variables selected by the researcher.Kaiser-Mayer-Olkin Measure of Sampling Adequacy (KMO MSA) greater than 0.50 and the value of Bartlett's Test of Sphericity (Sig.) is more smaller than 0.05. Based on the results of the KMO MSA factor analysis carried out using SPSS, the following results were obtained KMO MSA value is $0.755>0.50$ and the value of Bartlett's Test of Sphericity (sig.) $0.000<0.05$, then factor analysis in this research can be continued because it has fulfilled the first requirement.

Anti-Image Matrices are useful for knowing and determining variables which one is appropriate for use in factor analysis. Pay attention to the Anti-Image Correlation, in the table there is a letter code (a) which means the sign for Measure of Sampling Adequacy (MSA). Know the MSA value of each researched are as follows:

Work Motivation is 0.751 ; Work climate is 0.755 ; Job Satisfaction is 0.767; Performance is 0.751 . The requirements that must be met in factor analysis are MSA values $>0.50$. From the results above, it is known that the MSA values for all variables studied is $>0.50$, then the second requirement in this factor analysis is also fulfilled as table 8 .

Table 8. Measure of Sampling Adequacy (MSA)Test

\begin{tabular}{ll}
\hline Variable & Value \\
\hline Work Motivation & 0.751 \\
\hline Work Climate & 0.755 \\
\hline Job Satisfaction & 0.767 \\
\hline
\end{tabular}

T-test (Partial) Motivation Variables on Job Satisfaction. Based on the results of the t-test (partial) of the motivation variable on job satisfaction, it is known that the ttable value is 1.660 . So it can be concluded that the t-count value of the motivational variable (X1) is 3.903, which is greater than the t-table value of 1.660 , meaning that the motivation variable (X1) has a significant effect on job satisfaction (Y1) as seen on table 9 below.

Table 9. T-test Work Motivation

\begin{tabular}{|c|c|c|c|c|c|c|}
\hline \multicolumn{7}{|c|}{ Coefficients ${ }^{a}$} \\
\hline & & \multicolumn{2}{|c|}{ Unstandardized Coefficients } & \multirow{2}{*}{$\begin{array}{c}\text { Standardized } \\
\text { Coefficients } \\
\text { Beta }\end{array}$} & \multirow[b]{2}{*}{$\mathrm{t}$} & \multirow[b]{2}{*}{ Sig. } \\
\hline Model & & $\mathrm{B}$ & Std. Error & & & \\
\hline \multirow[t]{2}{*}{1} & (Constant) & 11,784 & 2,026 & & 5,817 & 000 \\
\hline & Motivasi & 407 & 104 & 367 & 3,903 &, 000 \\
\hline
\end{tabular}

a. Dependent Variable: Kepuasan Kerja

T-test (Partial) Work Climate Variables on Job Satisfaction. Based on the results of the t-test (partial) of the work climate variable on job satisfaction, it is known that the ttable value is 1.660 . So it can be concluded that the tcount value of the work climate variable (X2) is 5.555 which is greater than the ttable value of 1.660 , meaning that the work climate variable (X2) has a significant effect on job satisfaction (Y1) as table 10. 
Table 10. T-test Work Climate

\begin{tabular}{|c|c|c|c|c|c|c|}
\hline \multirow[b]{2}{*}{ Model } & & \multicolumn{3}{|c|}{$\begin{array}{l}\text { Coefficients } \\
\text { ANOVA }^{\mathrm{a}}\end{array}$} & \multirow[b]{2}{*}{$\mathrm{F}$} & \multirow[b]{2}{*}{ Sig. } \\
\hline & & $\begin{array}{l}\text { Sum of } \\
\text { Squares }\end{array}$ & df & Mean Square & & \\
\hline \multirow[t]{3}{*}{1} & Regression & 159,954 & 2 & 79,977 & 17,749 &, $000^{\mathrm{b}}$ \\
\hline & Residual & 437,086 & 97 & 4,506 & & \\
\hline & Total & 597,040 & 99 & & & \\
\hline
\end{tabular}

a. Dependent Variable: Kepuasan Kerja

b. Predictors: (Constant), Iklim Kerja, Motivasi

T-test (Partial) Job Satisfaction Variables on Performance. Based on the results of the t-test (partial) of the job satisfaction variable on performance, it is known that the ttable value is 1.660 . So it can be concluded that the tcount value of the job satisfaction variable (Y1) is 4,425 , which is greater than the ttable value of 1.660 , meaning that the job satisfaction variable (Y1) has a significant effect on performance (Y2) can be seen on table 11

Table 11. T-test Job Satisfaction

\section{Coefficients $^{a}$}

\begin{tabular}{|c|c|c|c|c|c|c|}
\hline \multirow[b]{2}{*}{ Model } & & \multicolumn{2}{|c|}{ Unstandardized Coefficients } & \multirow{2}{*}{$\begin{array}{c}\text { Standardized } \\
\text { Coefficients } \\
\text { Beta }\end{array}$} & \multirow[b]{2}{*}{$\mathrm{t}$} & \multirow[b]{2}{*}{ Sig. } \\
\hline & & $\mathrm{B}$ & Std. Error & & & \\
\hline \multirow[t]{2}{*}{1} & (Constant) & 12,121 & 1,815 & & 6,680 &, 000 \\
\hline & Kepuasan Kerja &, 406 &, 092 & ,408 & 4,425 &, 000 \\
\hline
\end{tabular}

a. Dependent Variable: Kinerja

F-Test of Motivation and Climate Variables on Job Satisfaction. Based on the results of the F test of motivation and climate variables on job satisfaction, it is known that the Ftable value is 3.09. The value of Fcount is 17.749 which is $>$ Ftable 3.09. So it can be concluded that there is a significant effect of the motivation variable and work climate $(\mathrm{X})$ simultaneously on the job satisfaction variable $(\mathrm{Y})$ as seen on table 12 below.

Table 12. F Test

\begin{tabular}{|c|c|c|c|c|c|c|}
\hline \multicolumn{7}{|c|}{ ANOVA $^{a}$} \\
\hline \multicolumn{2}{|c|}{ Model } & $\begin{array}{l}\text { Sum of } \\
\text { Squares }\end{array}$ & df & Mean Square & $\mathrm{F}$ & Sig. \\
\hline \multirow[t]{3}{*}{1} & Regression & 159,954 & 2 & 79,977 & 17,749 &, $000^{b}$ \\
\hline & Residual & 437,086 & 97 & 4,506 & & \\
\hline & Total & 597,040 & 99 & & & \\
\hline
\end{tabular}

a. Dependent Variable: Kepuasan Kerja

b. Predictors: (Constant), Iklim Kerja, Motivasi

The effect of work motivation on job satisfaction, based on the results of data analysis that has been carried out, it is known that motivation has a significant effect on job satisfaction of millennial lecturers. With this hypothesis $\mathrm{H} 1$ is accepted. This is evident from the t-count value of the motivation variable (X1) of 3.903, which is greater than the t-value of 1.660 , meaning that the motivation variable (X1) has a significant effect on job satisfaction (Y1). These results are supported by research conducted by Diyanti (2017), that work motivation during pandemic Covid-19 has a significant effect on job satisfaction for millennial lecturers. Motivation is a driving force or driving a person to behave in a certain way that can arise from within or 
outside the individual. Motivation is encouragement both from others and from oneself to do a job consciously and enthusiastically to achieve certain targets (Mulyadi, 2015). This is also supported by research conducted by Juniari (2015), that motivation has a positive and significant effect on job satisfaction. This shows that the better the motivation given, the job satisfaction will increase. In addition, the same thing is also obtained from research conducted by Nur'aeni (2011) and Werdhiastutie, Suhariadi, and Partiwi (2020) that motivation has a significant influence on job satisfaction. This shows that the higher the motivational factors given, the higher the job satisfaction. The explanation shows that the higher the level of a millennial lecturer has work motivation, the higher the job satisfaction of that person. Vice versa, the lower the level of one's work motivation, the lower one's job satisfaction.

The efect of work climate on job satisfaction, based on the results of data analysis it is known that the work climate has a significant effect on the job satisfaction of millennial lecturers during pandemic Covid-19 doing Tridharma. Thus hypothesis $\mathrm{H} 2$ is accepted. This is evident from the tcount value of the work climate variable (X2) of 5.555, which is greater than the ttable value of 1.660, meaning that the work climate variable (X2) has a significant effect on job satisfaction (Y1). These results are supported by research conducted by Diyanti (2017), that the work climate has a significant effect on job satisfaction. According to Wirawan (2013) and Chernyak-Hai and Rabenu (2018) that organizational climate is the quality of the internal environment that is relatively ongoing, experienced by members of the organization, influencing the behavior of each member. The results of the study are also supported by research conducted by Surachim (2008), that there is a fairly strong influence between organizational climate on employee job satisfaction. This shows that if the level of organizational climate during pandemic covid-19 is high, then the level of job satisfaction is high as well. Vice versa, if the level of organizational climate is low, the level of employee job satisfaction is low. This shows that the better the climate of a work environment, the more one's job satisfaction will be. Vice versa, a work climate that is not good or not conducive will cause a person's job satisfaction to be low.

The effect of job satisfaction on performance, based on the results of data analysis that has been carried out, it is known that job satisfaction has a significant effect on the performance of millennial lecturer during pandemic Covid-19. Meaning hypothesis H3 is accepted. This is evident from the tcount value of the job satisfaction variable (Y1) of 4,425, which is greater than the ttable value of 1.660 , meaning that the job satisfaction variable (Y1) has a significant effect on performance (Y2). These results are supported by research conducted by Diyanti (2017), that job satisfaction has a significant effect on performance. The results of Bernarto et al. (2020), also show that job satisfaction has a positive effect on performance. In addition, the results study of $\mathrm{Fu}$ and Deshpande (2014) also show that job satisfaction has a positive effect on employee performance. According to Meilani, Bernarto, Berlianto (2020), job satisfaction is an emotional state that is pleasant or unpleasant for employees to view their work. This shows that the higher the level of job satisfaction of a person, it will also increase the performance of that person, and vice versa.

\section{Conclusions}

Based on the results of research and discussion that have been carried out, and referring to the formulation of the existing problems, it can be concluded that: 1) Work motivation has a positive effect on job satisfaction of millennial lecturer. his shows that the higher the work motivation of educational staff, the more influential it will beon good job satisfaction, and vice versa the lower the motivation the work of education personnel, the lower the job satisfaction felt. Several factors influence work motivation of one's millennial lecturers during pandemic Covid-19 affected by internal factor consisting of desire and personal expectations; needs; fatigue and boredom doing Tridharma. External factors that can affected such as a pleasant work environment; there is adequate compensation adequate; there is an award for achievement; 2) Work climate has a positive effect on the job satisfaction of millennial lecturer. This shows that the better the work environment, the better job satisfaction, and vice versa, the worse the work environment, the lower the job satisfaction felt by millennial generation lecturers during the Covid-19 pandemic; 3) Job satisfaction has a positive effect on the performance of millennial lecturer done no stress. This shows that the higher job satisfaction of millennial lecturer will also affect the good performance, and the lower the job satisfaction make the lower the quality of performance during pandemic Covid-19. The factors that influence job satisfaction are opportunities for advancement; job security; salary; working conditions; communication; and facilities. The suggestions that can be given for further research are that further research is expected to be able to use or add other variables that are not used in this study, so that later it will be known exactly what are the factors that can affect job satisfaction and milleniall lecturer's performance. 


\section{References}

Asf, Jasmani \& Syaiful, Mustofa. (2013). Supervisi Pendidikan : Terobosan Baru dalam Peningkatan Kinerja Pengawas Sekolah dan Guru. Yogyakarta. Ar-Ruzz MediaFahmi.

Ansar, R., Karim,A. Osman,Z and Fahmi,M.S. (2019). Gender, Educational Qualification and Ethnicity Differences in Personal Financial Management Practices among Generation Y in Malaysia, Asian Journal Econ. Bus. Account., vol. 12, no. 1, pp. 1-7, 2019, doi: 10.9734/ajeba/2019/v12i130143.

Bernarto, I., Bachtiar, D., Sudibjo, N., Nurpatria, I., Suryawan, Purwanto, A., Asbari, M. (2020). Effect of Transformational Leadership, Perceived Organizational Support, Job Satisfaction Toward Life Satisfaction: Evidences from Indonesian Teachers. International Journal of Advanced Science and Technology, Vol. 29: No. 03, (2020), 5495 - 5503.

Brahmasari, Ida, Ayu and Agus Suprayitno, (2008). Pengaruh Motivasi kerja, Kepemimpinan dan Budaya Organisasi Terhadap Kepuasan Kerja Karyawan serta dampaknya pada Kinerja Perusahaan" (Studi kasus pada PT. Pei Hai Internasional Wiratama Indonesia). Jurnal Manajemen dan Kewirausahaan Vol.10 No.2 pp 124-135.

Chernyak-Hai, L., \& Rabenu, E. (2018). The new era workplace relationships: Is social exchange theory still relevant? Industrial and Organizational Psychology: Perspectives on Science and Practice, 11(3), 456-481.

Diyanti. (2017). Pengaruh Motivasi Kerja dan Iklim Kerja Terhadap Kepuasan Kerja dan Implikasinya Terhadap Kinerja Tenaga Kependidikan Institut Pertanian Bogor. Jurnal Aplikasi Bisnis dan Manajemen, 3 (3), 2528-5149

Fu, W., \& Deshpande, S. P. (2014). The impact of caring climate, job satisfaction, and organizational commitment on job performance of employees in a China's insurance company. Journal of Business Ethics, 124(2), 339-349.

Juniari, Ni Kadek Eni. (2015). Pengaruh Motivasi Terhadap Kepuasan Kerja dan Kinerja Pegawai Negeri Sipil (PNS) di Sekolah Tinggi Pariwisata Nusa Dua Bali. Jurnal Ekonomi dan Bisnis Universitas Udayana, 4 (11), 823-840

Kotler, P., Amstrong, G. (2014). Principle of Marketing. 14 Edition. England: Pearson Education, Inc.

Luntungan, I; Vitayala S. A; Hubeis, E.S.; Maulana, A. (2014). Strategi Pengelolaan Generasi Y di Industri Perbankan. Jurnal Manajemen Teknologi, Vol.13(2), 2014: 219-240.

Masnita, Y., Puspitasari, P., \& Risqiani, R. (2019). The mediating effect of psychological ownership on human resources management bundle and job satisfaction ownership. Journal of Economics, Business, \& Accountancy Ventura, 22(2), 193-201.

Meilani, Y. F. C. P., Bernarto, I., \& Berlianto, M. P. (2020). Impact of Motivation, Discipline, Job Satisfaction on Female Lecturer Performance at PH University. MEC-J (Management and Economics Journal), 4(2), 93-104.

Mulyadi, D. (2015). Perilaku Organisasi dan Kepemimpinan Pelayanan. Bandung. Alfabeta.

Novitasari, D., Asbari, M., Wijaya, M. R., \& Yuwono, T. (2020). Effect of Organizational Justice on Organizational Commitment: Mediating Role of Intrinsic and Extrinsic Satisfaction. International Journal of Science and Management Studies (IJSMS), 3(3), 96- 112.

Nur'aeni. (2011). Pengaruh Motivasi, Kompetensi dan Komitmen Terhadap Kinerja Dosen Perguruan Tinggi Swasta di Kopertis Wilayah II Palembang. Jurnal Manajemen dan Bisnis, Vol. 1 No. 2, pp. 101-129

Samsudin, Sadili. (2010). Manajemen Sumber Daya Manusia, Cetakan Ke-3. Bandung. Pustaka Setia

Suarningsih, P. dan Alamsyah, A. (2013). Pengaruh Iklim Organisasi terhadap Komitmen Organisasional dan Kinerja Karyawan di Rumah Sakit. Jurnal Aplikasi Manajemen, Vol. 2, No. 2: 233-240.

Sugiyono, P (2018) Metode Penelitian Manajemen. CV ALFABETA.

Surachim, Ahim. (2008). Pengaruh Iklim Organisasi Terhadap Kepuasan Kerja Karyawan pada Divisi Pharmaserve di PT. Combiphar Jakarta. Jurnal Pendidikan Manajemen Bisnis, 8 (1)

Susanty, Etty. (2012). Pengaruh Iklim Organisasi Terhadap Kepuasan Kerja dan Komitmen Karyawan pada Universitas Terbuka. Jurnal Organisasi dan Manajemen, 8 (2), 121-134.

Undang-undang No 14 Tahun 2005 tentang Guru dan Dosen Standar Pendidikan Nasional, Jakarta: CV. Tamita Utama.

Werdhiastutie, A., Suhariadi, F., and Partiwi, S. G. (2020). Achievement Motivation as Antecedents of Quality Improvement of Organizational Human Resources. Budapest International Research and Critics Institute-Journal (BIRCI-Journal) (3),747-752.

Wibowo. (2014). Manajemen Kinerja, Edisi Keempat. Jakarta. Rajawali Press

Wirawan. (2013). Budaya dan Iklim Organisasi Teori Aplikasi dan Penelitian. Jakarta. Salemba Empat.

Zeffane, R., \& Melhem, S. J. B. (2017). Trust, job satisfaction, perceived organizational performance and turnover intention. Employee Relations. 
Zhao, Y. (2018). Managing Chinese millennial employees and their impact on human resource management transformation: an empirical study. Asia Pacific Business Review, 24(4), 472-489.

https://kelembagaan.ristekdikti.go.id/index.php/koordinasi-perguruan-tinggi-swasta/. Tanggal akses 20 Agustus 2021. 